\title{
FROM ABSTRACTION TO UNSAYING: HOW THE EUNOMIAN CONTROVERSY CHANGED GREGORY OF NYSSA'S APHAIRETIC ETHICS TO AN APOPHATIC ETHICS ${ }^{* *}$
}

In early Christian thinking negative theology was often applied for primarily polemical purposes, as Christian thinkers engaged critically with Hellenic philosophy and religion. The fundamental purpose of applying negative theology in these polemical contexts was to assert the distinction between God and everything else ${ }^{1}$. Often this polemical aspect of negative theology has been overlooked. David Palmer rightly noted that modern scholars have too often attempted to fit the negative theology of the apologetic fathers into a systematic framework "which is not in keeping with the method and purpose of the apologists themselves" .

A good example of a study that did emphasize the polemical aspect in Patristic thinking was Ronald Heine's work on Gregory of Nyssa. According to Heine the polemics against Eunomius on the one hand and sorts of Origenism on the other shaped Gregory's later thinking, especially his negative theology and ethics ${ }^{3}$. Heine argued, however, that the changes from the early On the Inscriptions of the Psalms (c. 377) to the late The Life of Moses (c. 390-394) are

* Johannes Aakjær Steenbuch - Ph.D., Cand. mag. and BA in philosophy, alumnus of the Department of Media, Cognition and Communication of the University of Copenhagen (DK); e-mail: johannesas@gmail.com.

** This article was presented as a shorter paper at the The International Patristic Conference Fathers of the Church in the Polemics Against Heresies at the Catholic University of Lublin, Poland, May 2016. I participated in the conference with the support of the Danish Ecumenical Study Grant (Det økumeniske studielegat).

${ }^{1}$ Cf. R. Sokolowski, The God of Faith and Reason: Foundations of Christian Theology, Washington D.C. 1995, 32.

${ }^{2}$ Cf. D.W. Palmer, Atheism, Apologetic, and Negative Theology in the Greek Apologists of the Second Century, VigCh 37/3 (1983) 236.

${ }^{3} \mathrm{Cf}$. R. Heine, Perfection in the Virtuous Life: A study of the relationship between edification and polemical theology in Gregory of Nyssa's "De Vita Moysis", Cambridge (MA) 1975. Heine argued that Gregory's discussion of the two first theophanies in On the Life of Moses reflects an antiEunomian emphasis, while the third theophany and Gregory's notion of spiritual ascent expresses an anti-Origenist argument. See ibidem, p. 194-195; see also H. Langerbeck, Zur Interpretation Gregors von Nyssa, ThL 82 (1957) 81-90. 
not of a radical kind, but rather a change in emphasis ${ }^{4}$. In the following I will discuss to what degree this characteristic should be taken for granted.

In On the Inscriptions of the Psalms some sort of negative theology does only seem to be a stage before a final likeness to God, which can be described partly in positive terms, for example by using metaphors of light. This has changed in On the Life of Moses as the final stage is now conceived of in terms of darkness and ineffability. This also has consequences for Gregory's ability to make an adequate account of the virtuous life, as Gregory admits of being incapable of capturing the virtues of Moses in his treatise. The result is that imitation of God must now consist in following Christ in the sense of imitating his works in history, rather than imitating the divine form or nature itself.

Between these two treatises is the Eunomian controversy, in which Gregory's polemical thought played a significant role in developing his negative theology. The application of this polemical aspect of negative theology helped change Gregory's thinking from a negative theology based on abstraction to one based on unsaying or apophasis. My claim is that these changes also resulted in changes in Gregory's ethics, his moral epistemology in particular. It was, to a large degree, the Eunomian controversy, which helped Gregory to develop his aphairetic moral epistemology into an apophatic moral epistemology. The link between apophatic theology and moral epistemology is Gregory's theory of $\dot{\varepsilon} \pi i v o t \alpha$ or conception which can be considered the epistemological equivalent of so-called $\dot{\varepsilon} \pi \dot{\varepsilon} \kappa \tau \alpha \sigma i \varsigma$. Finally, the result of this connection is, that imitation of God is conceived of in terms of following rather than of likeness.

1. Negative theology? Negative theology can fundamentally be defined as the practice of using negative definitions for describing and referring to God. In Middle- and Neo-Platonism negative theology was applied as abstraction or removal in order to gain a clear conception of the One. This method was taken over by Christian Neo-Platonists such as Clement of Alexandria 5 .

Negative theology is often understood as an intellectual or ethical method, a "way" or via negativa. But in early Christian thinking it was not so much a philosophical way in the later sense. Rather, for the early apologists, negative theology was a polemical tool for dismantling the claims of especially Pagan philosophy and religion. By emphasizing the incomprehensibility of God and the difference between creator and creation, apologists could demonstrate the absurdity of, e.g., Greek religion as well as Greek philosophy ${ }^{6}$.

The terms "apophatic" theology and "negative" theology are often used as synonyms. But it would be more precise to understand apophatic theology as a subgenre of negative theology. Negative theology includes the way of

\footnotetext{
${ }^{4}$ Cf. Heine, Perfection in the Virtuous Life, p. 2.

${ }^{5}$ Cf. H.F. Hägg, Clement of Alexandria and the Beginnings of Christian Apophaticism, Oxford 2006.

${ }^{6}$ Cf., e.g., Aristides, Apologia.
} 
removal, or the via remotionis on the one hand, as well as the way of negation, or the via negationis on the other. As Raoul Mortley and others have pointed out, the distinction can be traced back to Aristotle's distinction between

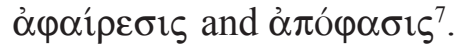

By ó $\varphi \alpha i p \varepsilon \sigma i \varsigma$ should be understood removal or abstraction in the sense that certain properties are abstracted from an object, in order to distinguish it more clearly from other objects ${ }^{8}$. An example of an aphairetic negative theology can be found in the one criticized by Gregory of Nazianzus. Gregory notes that defining God solely through negations is like saying what two times five is by counting all the numbers besides ten ${ }^{9}$. This approach, it could be argued, is abstractive, since it ends up confirming the positive value of the number by negation. But the result of this process is not itself a negative definition.

By ó ó́ $\varphi \alpha \sigma i \varsigma$ should be understood unsaying or negation in the more general sense that a claim about an object is negated. While abstraction results in more definite knowledge about the object in question, negation in the sense of $\alpha \pi$ ó $\alpha \sigma i \varsigma$ does not ${ }^{10}$. It should be noted that negation is not the same as opposition. As Mortley notes "common-sense often extends negation into opposition, though a coherent logical account would scarcely do"11. The claim that God is not, for example, material does not make him belong to a class that is opposite to what is material, but only gives us an indefinite conception about what God is not.

Though the precise distinction between the terms ỏ $\varphi \alpha i \rho \varepsilon \sigma ı \varsigma$ and $\alpha \operatorname{só} \varphi \alpha-$ $\sigma i \varsigma$ was often not preserved in later philosophy, the distinction can be used to describe different approaches to negative theology. As abstraction, negative theology searches for distinct and definite notions about the divine by distinguishing the divine from other things. But as negation or unsaying, negative

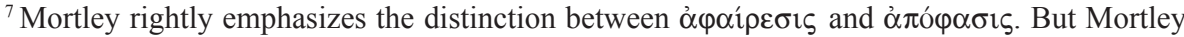
does not always put enough weight on the polemical aspect of early negative theology, I believe. Cf. R. Mortley, From Word to Silence, II: The Way of Negation, Christian and Greek, Bonn 1986, 261; Aristoteles, Ethica nicomachea 1145a; idem, Metaphysica 1061a 29. Aristotle argues that God and the brutes have that in common that they are not virtuous. This is not a common privative property. It does not mean that they could have been virtuous but are not. The lack of virtue in this case only means that God and the brutes are common in not being describable in terms of virtue or vice.

${ }^{8}$ In Thomas, the via remotionis is a way of clearly distinguishing between Creator, as the first cause, and creature. See Thomas, Summa Contra Gentiles 1.10-102. Celsus (2nd c.) uses ỏvó $\lambda v \sigma i \varsigma$ instead of $\alpha \varphi \alpha i \rho \varepsilon \sigma ı \varsigma$, but it has the same function of clearly distinguishing between what belongs to a subject and what not. Cf. J. Daniélou, Gospel message and Hellenistic culture, Westminster 1973, 340-341.

${ }^{9}$ Cf. Gregorius Nazianzenus, Oratio 28 (De theologia), 9.

${ }^{10}$ Mortley suggests that it was such indefiniteness that made the apophatic method unattractive to Aristotle. Cf. R. Mortley, What is Negative Theology? The Western Origins, "Prudentia" supplementary number: Via Negativa Conference - University of Sydney (1981) 10.

${ }^{11}$ Ibidem, p. 9.
} 
theology points to the ultimate indefiniteness and incomprehensibility of the divine by unsaying every known thing ${ }^{12}$.

The distinction can also be applied to moral epistemology. By moral epistemology I mean our theory of how we can obtain moral knowledge, for example by describing the character or life of virtuous persons. When applied to moral epistemology, the distinction between abstraction or removal on the one hand and negation or unsaying on the other results in different moral epistemologies. In the first case, ethics will often be taken to consist in descriptions of virtuous persons who have separated (or "abstracted") themselves from material things while in the latter case, ethics will often be taken to consist in continuous negations of definite descriptions of what virtue is in order to make it clear that virtue cannot be achieved in any final way.

That there is a connection between negative theology and ethics is obvious in the case of Gregory of Nyssa ${ }^{13}$. For Gregory, the polemical use of negative theology seems to have changed his theology to a more radically apophatic one ${ }^{14}$. This change is also reflected in his moral epistemology. A good way of exemplifying this is a comparison of his early treatise On the Inscription of the Psalms and his late treatise On the Life of Moses. In both treatises Moses is used as an example of a virtuous person. But Gregory's reflections on the possibility of giving an adequate description of the life of virtuous persons differ much in the two treatises.

There are quite a few examples of diachronic readings of the developments in Gregory of Nyssa's thinking. As noted in the introduction, Ronald Heine discussed how Gregory's thinking had developed from his early treatise $O n$ the Inscriptions of the Psalms to a more apophatic one in his On the Life of Moses. Jean Danielou has also noted how Gregory's thinking became less Platonic as it developed ${ }^{15}$. This is obvious in how Gregory reshaped the Platonic allegory of the cave. It is not possible for human beings to exit the cave, but as Christ has himself been incarnated in our world it is now possible to gaze at the infinity of God without exiting the cave. As Anthony Meredith notes, "for Gregory knowledge of the reality, incomprehensibility and infinity of God are

${ }^{12}$ The purpose of apophatic theology is not just saying that God is different from other things but that God is "differently different". Cf. Sokolowski, The God of Faith and Reason, passim; J. Wissink, Two Forms of Negative Theology Explained Using Thomas Aquinas, in: Flight of the Gods: Philosophical Perspectives on Negative Theology, ed. I.N. Bulhof - L. ten Kate, Fordham 2000, passim.

${ }^{13}$ Cf. J. Steenbuch, Doing the Unthinkable: Theology and Moral Epistemology in Three Early Christian Thinkers, Copenhagen 2014, passim.

${ }^{14}$ Giulio Maspero has characterized Gregory's negative theology as consisting in four fundamental elements. The elements are "(1) the division between created and uncreated, (2) the theory

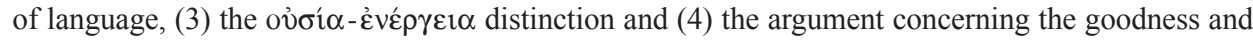
power of God". To this I think could be added a fifth, namely the polemical function of negative theology. Cf. The Brill Dictionary of Gregory of Nyssa, ed. L.F. Mateo-Seco - G. Maspero, Brill 2009, 73.

${ }_{15}$ Cf. J. Daniélou, Le symbole de la caverne chez Grégoire de Nysse, in: Mullus. Festschrift Theodor Klauser, Münster 1964, 43-51. 
not arrived at by abstraction from the facts of nature and history, but by knowledge of and immersion in them"16.

Though this is well-known, I will make a short comparison before introducing the Eunomian controversy and finally a discussion on how this controversy might have led to the changes in Gregory's negative theology and consequently his moral epistemology. An important link is Gregory's theory on conception or $\dot{\varepsilon} \pi$ ívor $\alpha$, which, I will argue, is the epistemological parallel to the idea of continuous or never-ending progress in virtue, so-called $\dot{\varepsilon} \pi \dot{\varepsilon} \kappa \tau \alpha \sigma \imath \varsigma$, which Gregory in particular develops in the treatise On the Life of Moses.

2. Moses according to the early Gregory. In On the Inscriptions of the Psalms Gregory argues that the headings of the biblical Psalms contain certain ethical teachings. Gregory argues that the inscriptions of the Psalms present a subtle teaching intended to direct the hearer to the virtuous way of life by cer-

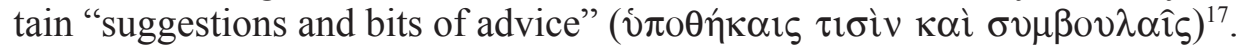

There is a certain sequence in these suggestions, which Gregory later in the

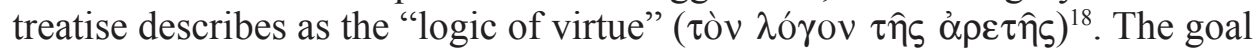
of "the economy of the Holy Spirit", says Gregory, is "to set forth the previous accomplishments of holy men for guidance", so that by this represenation we can be led to that good which is "equal and similar".

One of these holy men is Moses. In the treatise Gregory attempts to give a "description of what that sublime Moses" was like ${ }^{19}$. Moses, says Gregory, willingly "shook of his royal dignity" and "banished himself from human society". He focused "steadfastly in undistracted solitude on the contemplation of invisible things" and after this he was "illuminated by the inexpressible light". Moses had a "keen vision in the divine darkness, and beheld the One who is invisible in it", says Gregory.

After his vision Moses "bore upon his face the tokens" ( $\tau \dot{\alpha} \sigma \hat{\jmath} \mu \pi \beta \mathrm{o} \lambda \alpha)$ of

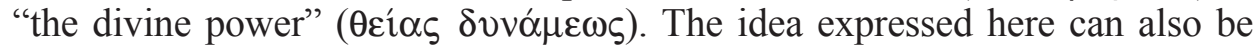
found in Gregory's interpretation of Psalm 4:7, "The light of your face has been imprinted on us, Lord" (Ps 4:7). This is taken to mean that "the face of God"

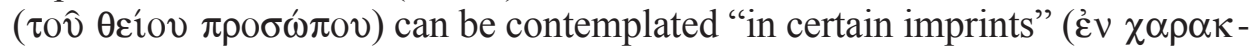
$\tau \eta \hat{\rho} \sigma \dot{\imath} \tau \imath \sigma \iota \theta \varepsilon \omega \rho \circ \tilde{\mu} \mu \varepsilon v o v)^{20}$. These imprints are the virtues in the human soul,

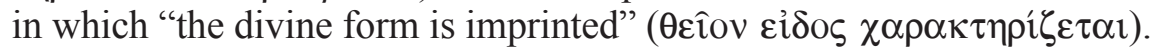

Virtue is hidden to immediate sense-perception, but it is possible "to find

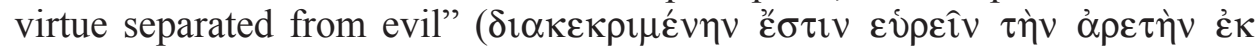

${ }^{16}$ A. Meredith, Plato's Cave ("Republic" VII 514a-517e) in Origen, Plotinus, and Gregory of Nyssa, StPatr 27 (1991) 60.

${ }^{17} \mathrm{Cf}$. Gregorius Nyssenus, In inscriptiones Psalmorum, ed. J. Donough, GNO 5, Leiden 1962, 28.

${ }^{18}$ Cf. ibidem, GNO 5, 151.

${ }^{19} \mathrm{Cf}$. ibidem, GNO 5, 51.

${ }^{20} \mathrm{Cf}$. ibidem, GNO 5, 35 . 


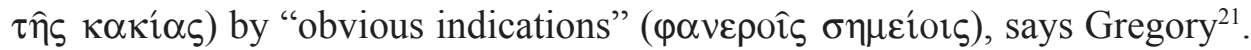

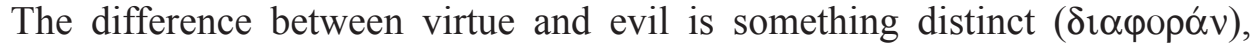
says Gregory, and in this case he talks of different kinds of joy or well-being

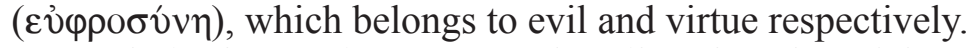

Early in the treatise Gregory describes the telos of the virtuous life as be-

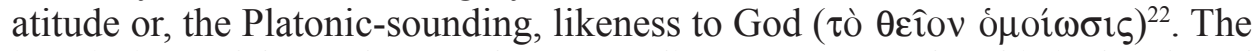
inscriptions of the Psalms teaches, according to Gregory, that this is developed in three stages: First, the separation from evil, then, the meditation on sublime things, and finally, the actual likeness to $\operatorname{God}^{23}$.

The final stage in spiritual progress is illumination, as is clear from the example of Moses who ends up shining with the divine tokens. Gregory hardly asserts the theme of "divine darkness" at all in On the Inscriptions, as he will in his later works, even if he does mention it once in his description of Moses $^{24}$. Rather Gregory uses light-metaphors, as when he notes that we are united with the divine when "the brightness of God" shines in our conduct ${ }^{25}$. By changing to the good "one receives a radiant and snowy expression instead of a black and murky one".

Gregory's moral epistemology is in this context primarily a positive or a kataphatic one, with the negative, abstractive element being instrumental in attaining positive insight. Gregory's descriptions of Man as a microcosm, representing the music of the universe in the banquet of the virtues, does also suggesta positive moral epistemology ${ }^{26}$.

Even if Gregory in On the Inscription of the Psalms talks about the "inexpressible light" and the One who is "invisible" in the divine darkness, this does not amount to a truly apophatic theology, since it does not depend on a continuous negation in the sense of unsaying that which is contrary to the good.

Gregory does, however, use somewhat apophatic formulations in the treatise: By noting that the goal of virtue is peace and rest, the author of the Psalms points out what is contrary to virtue by means of silence, says Gregory ${ }^{27}$. In this way evil is described by means of negative statements. But this is not the same as defining the good in negative terms. It may be that evil already at

${ }^{21}$ Cf. ibidem, GNO 5, 34.

${ }^{22} \mathrm{Cf}$. ibidem, GNO 5, 26; Plato, Theaetetus 176b.

${ }^{23}$ This three-stage notion of the virtuous life has been proposed as a basic key to Gregory's spiritual teachings in general, for example by the early Jean Daniélou. He eventually changed his views and argued that Gregory's notion of $\dot{\varepsilon} \pi \dot{\varepsilon} \kappa \tau \alpha \sigma ı \varsigma$ is not compatible with this notion. It does seem, however, that at least Gregory's early ethics is based upon this three-stage notion.

${ }^{24}$ Heine noted that Rondeau is wrong in claiming that Gregory does not assert the theme of "divine darkness" at all in On the Inscriptions. Cf. Heine, Perfection in the Virtuous Life, p. 53-54; M.J. Rondeau, Exégèse du Psautier et anabase spirituelle chez Grégoire de Nysse, in: Epektasis: Mélanges patristiques offerts au cardinal Jean Daniélou, Paris 1972, 517.

${ }^{25} \mathrm{Cf}$. Gregorius Nyssenus, In inscriptiones Psalmorum, GNO 5, 51.

${ }^{26}$ This is basically Pythagorean. Cf. ibidem, GNO 5, 30-34.

${ }^{27}$ Cf. ibidem, GNO 5, 37. 
this point for Gregory could be defined as privation ( $\sigma \tau \varepsilon \rho \eta \sigma ı \varsigma)$, but it is not something that he develops in any comprehensive way. The need for a double negation, so to speak, as a manner of affirming the good by negating evil, does not seem to be the primary focus.

Negative definitions of evil have a highly aphairetic or abstractive function. Spiritual progress consists in separation from evil. When the Word transforms us into "the divine likeness" it proceeds "methodically and orderly" as it first separates us from evil, then trims off the excess of matter and then strips off the things which hinder the representation of the divine in the human soul. Finally "it forms Christ in us" by means of the "forms of virtue".

Gregory initially notes that spiritual progress ("entrance to the good") starts with "the departure from those things which are opposite to it" and that the "participation in what is superior occurs by means of this entrance" 28 . But this does not amount to an apophatic definition of the good or virtue. It is only at the lower levels that negations are relevant, and the purpose of these negations are to affirm definiteness, not indefiniteness. The third, highest level, actual likeness to God, is not described in negative definitions, but in terms of a positive likeness to the divine form.

This idea, that the divine form is imprinted in the virtues of the human soul, suggests a rather positive moral epistemology. What we are dealing with here is, in other words, an abstractive or aphairetic ethics, rather than an apophatic one.

3. Moses according to the later Gregory. Gregory's later treatise On the Life of Moses seems to have been written as a reply to a Caesarius, who had asked for advice on how to lead a life fitting for a priest. In the treatise, the life of Moses is presented as an allegory for the ideal priesthood.

In the introduction to On the Life of Moses, Gregory sets out to obtain

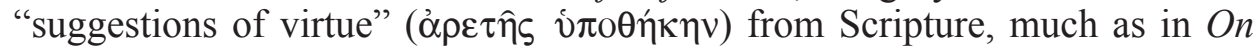
the Inscriptions of the Psalms, where Gregory searches the Psalms for "suggestions and bits of advice" (i் attainment of virtue ${ }^{29}$.

The history of the life of Moses is as a beacon, which brings "our soul to the sheltered harbor of virtue", says Gregory ${ }^{30}$. The purpose of Gregory's treatise is to bring out "the spiritual understanding which corresponds to the history" 31 . This idea seems similar to the idea in On the Inscriptions of the Psalms that the "economy of the Holy Spirit" presents "the previous accomplishments of holy men for guidance". But where Gregory had in his early treatise On the

${ }^{28}$ Cf. ibidem, GNO 5, 39.

${ }^{29}$ Cf. idem, De vita Moysis, Praefatio 15, ed. J. Daniélou, SCh 1bis, Paris 1987, 54; idem, In inscriptiones Psalmorum, GNO 5, 28.

${ }^{30}$ Cf. idem, De vita Moysis, Praefatio 13, SCh 1bis, 52.

${ }^{31} \mathrm{Cf}$. ibidem, Praefatio 15, SCh 1bis, 54. 
Inscriptions of the Psalms "enthusiastically" welcomed the invitation to investigate the spiritual meaning of the inscriptions, he is much more reluctant in the work on Moses: "It is beyond my power to encompass perfection in my treatise or to show in my life the insights of the treatise", says Gregory ${ }^{32}$.

But the most striking difference between the introductions to the two treatises is the reasoning that immediately follows Gregory's reservations in $\mathrm{On}$ the Life of Moses. Gregory notes that where the perfection of "everything that can be measured by the senses" is marked off by definite boundaries, the perfection of virtue knows no limit, since "no good has a limit in its own nature" ${ }^{33}$. The good is, in other words, infinite, which means that everything that is marked off by boundaries is not perfect virtue.

From this follows that it is "undoubtedly impossible to attain perfection" ( $\tau 0 \hat{v} \tau \varepsilon \lambda \varepsilon i ́ 0 v$ ), says Gregory ${ }^{34}$. Gregory then introduces the idea of never-ending progress in virtue (so-called $\dot{\varepsilon} \pi \dot{\varepsilon} \kappa \tau \alpha \sigma ı \varsigma)$ ): "the perfection of human nature consists perhaps in its very growth in goodness", says Gregory ${ }^{35}$. What we are dealing with here is, in other words, a truly apophatic account of virtue, where it is precisely the indefiniteness of virtue that characterizes its perfection. This seems to be the reason why Gregory must admit that he is not able to encompass perfection in his treatise On the Life of Moses. On the Life of Moses.

Throughout the treatise Gregory discusses Moses' three theophanies. Gregory takes the first theophany, that of the burning bush, to symbolize a spiritual experience, where "the eyes of our soul" are illuminated with the rays of God $^{36}$. God's commandment, that Moses take off his sandals, means that for this illumination to take place, we must purify "our opinion concerning nonbeing" ${ }^{37}$. Moses learns that by separating himself from worldly or material things, he draws near to God.

In the second theophany, the theme of light is replaced by a theme of darkness. Gregory himself notes that "[w]hat is now recounted seems somehow to be contradictory to the first theophany" ${ }^{38}$. Knowledge about God comes at first as light and is as such perceived as contrary to darkness. But where truth was first defined as "not to have a mistaken apprehension of Being", now knowledge of the divine is defined as "the seeing that consists in not seeing".

The main theme of Gregory's interpretation of the third theophany is that of never-ending progress in virtue. When God walks by Moses who had wished to see God, Moses is only allowed to see God's back, and not his face. This does not mean that Moses' request to see God was not granted, but only

\footnotetext{
${ }^{32}$ Cf. ibidem, Praefatio 3, SCh 1bis, 46.

${ }^{33}$ Cf. ibidem, Praefatio 5, SCh 1bis, 48.

${ }^{34}$ Cf. ibidem, Praefatio 8, SCh 1bis, 50.

${ }^{35} \mathrm{Cf}$. ibidem, Praefatio 10, SCh 1bis, 50.

${ }^{36} \mathrm{Cf}$. ibidem II 19, SCh 1bis, 116.

${ }^{37} \mathrm{Cf}$. ibidem II 22, SCh 1bis, 118.

${ }^{38} \mathrm{Cf}$. ibidem II 162, SCh 1bis, 210.
} 
that "[t]he divine voice granted what was requested in what was denied" 39 . Gregory connects this to a theme of hope: "Hope always draws the soul from the beauty which is seen to what is beyond, always kindles the desire for the hidden through what is constantly perceived".

The first part of Gregory's treatment of Moses' theophanies in On the Life of Moses is compatible with his treatment in On the Inscriptions, where Moses is depicted as one who has gone through the three levels of spiritual progress. The second part is more likely to be incompatible with On the Inscriptions, though Gregory does mention the divine darkness in the early treatise. What is even more obviously incompatible with the early account is the claim that Moses never attains a final vision of the divine nature.

Moses does not end up representing the divine form in his face and Gregory does not attempt to present an adequate account of Moses' virtue. Neither are there any notions of the virtuous soul as a microcosm reflecting the music of the universe. The virtue of Moses seems to be completely ineffable, just as the divine nature, that he reflects.

4. The effects of the Eunomian controversy. The Neo-Arian Eunomius of Cyzicus and other Anomœans argued that the Son was of a different nature (ovं ${ }^{\prime} \alpha$ ) from the Father. Against (neo-)Arianism Gregory affirmed that "all hope of salvation should be placed in Christ", and thus defended a Christocentrism that made it crucial to ensure the theological or ontological as well as epistemological status of the $\mathrm{Son}^{40}$. Christ is himself divine, and it is only through him that we know God.

Eunomius claimed that the Father and the Son must have essentially different natures or essences, since the Father is ungenerate ( $\alpha \gamma \varepsilon \dot{\varepsilon} v \eta\rceil 0 \varsigma)$, while the Son is generate ( $\gamma \varepsilon v \nu \eta \tau o ́ s)$. Eunomius maintained that the term "ungenerate" is derived from the very essence of God, about which we can have a direct knowledge. God, the Father, is first of all to be defined as ungenerate essence ${ }^{41}$. Eunomius claimed that since God's ungeneracy is an essential property, the term $\dot{\alpha} \gamma \dot{\varepsilon} v v \eta \tau o \zeta$ is not an invention ( $\dot{\varepsilon} \pi^{\prime} v o 1 \alpha$ ) of human thought and speech. Neither is it a privative definition (in terms of $\sigma \tau \varepsilon \dot{\varepsilon} \rho \sigma \imath \varsigma$ ), nor is it a relational property ${ }^{42}$.

In Gregory's defense of orthodox trinitarianism, the notion of divine infinity became central. Gregory, against Eunomius, argued that since the divine

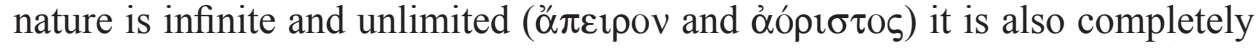
incomprehensible and unknowable for created and limited beings. This should be understood in strictly apophatic terms. Saying that God is infinite is simply

\footnotetext{
${ }^{39}$ Cf. ibidem II 232, SCh 1bis, 266.

${ }^{40} \mathrm{Cf}$. idem, Contra Eunomium II 50.

${ }^{41}$ Cf. Eunomius, Apologia 30, 841.

${ }^{42}$ Cf. ibidem 30, 844.
} 
a way of saying that God is not like any finite thing which can be known ${ }^{43}$.

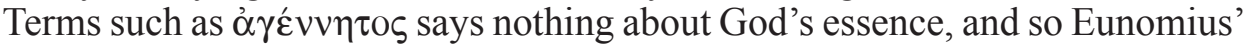
arguments against trinitarianism must be wrong.

For this argument to work Gregory had to come up with an alternative to Eunomius' idea that our names for God are derived positively from the divine nature. Gregory defended the legitimacy of inventing new names for God:

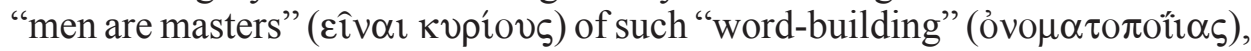
"adapting their appellations to their subject, each man according to his judgment" ${ }^{\prime \prime}$. There is no absurdity in having to invent names for the ineffable divine nature, such as Eunomius had claimed. We are, says Gregory, fully justified in applying new words in respect to God himself.

It turns out that apophatic theology in the Eunomian controversy was much more useful for Gregory's polemical purposes than aphairetic theology was. We do not now gain an idea of God by removing that which is not God from our ideas in order to gain a direct insight into the essence of God, but rather make up names for the incomprehensible divine nature by negation. We can have no directly comprehensive idea of the good, but we can have an indirect notion through what could be called an ontological-epistemological double negation - the epistemological unsaying or $\alpha \dot{\alpha}$ ó $\varphi \alpha \sigma ı \varsigma$ of evil, understood as the ontological privation or $\sigma \tau \varepsilon \dot{\rho} \eta \sigma i \varsigma$ of goodness.

But because we are not here dealing with a simple logical double-negation, the unsaying of privation does not give us a direct, positive account of the good. Though the divine nature is of course ontologically independent of evil, evil has in this sense an epistemological primacy before the good $^{45}$. Evil can be comprehended because it is limited, while the good can only be comprehended as the negation or unsaying of limitations. But unsaying does not help us to gain a more definite idea of the good by separating it from evil, as abstraction or removal does, but only gives us a still more indefinite idea of the good by denying that which ontologically lacks goodness.

From Gregory's polemics against Eunomius followed a growing conviction that language works conceptually and that talk about the divine essence is possible in spite of its infinity, though only in apophatic terms. When applied to the divine nature, conception uses negative definitions by saying what God is not. Negative definitions are not a way of reaching a more comprehensive positive definition of the divine nature, but of unsaying language altogether as a way of pointing beyond language to that which cannot be named.

Making up new names from negative definitions of God is not something which can finished at once, but a continuous process. Gregory defines conception as the method by which we discover things that are unknown, going on

${ }^{43}$ Cf. R.S. Brightman, Apophatic Theology and Divine Infinity in St. Gregory of Nyssa, GOTR 18 (1973) 111.

${ }^{44}$ Cf. Gregorius Nyssenus, Contra Eunomium II 148.

${ }^{45}$ Cf. Steenbuch, Doing the Unthinkable, p. 159. 
to further discoveries by means of what adjoins to and follows from our first perception with regard to the thing studied ${ }^{46}$. As we invent new names for things we gain the possibility of going still further. This is true in particular for theological language, it seems.

Even seemingly positive definitions for God are implicitly apophatic definitions in so far as they refer to the divine nature. Saying that God is just is equivalent to saying that he is not unjust, while saying that he is good is equivalent of saying that he is not evil ${ }^{47}$. What we can know is God's activity

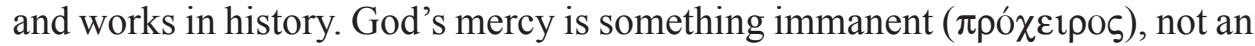
abstract property of the divine nature ${ }^{48}$.

That there is also a contemplative and spiritual aspect of conception becomes clear as Gregory during the polemics against Eunomius discusses Abraham's journey out of Chaldea. Abraham desired to behold the archetype of all beauty and he raised his thoughts as far as possible above the common boundaries of nature ${ }^{49}$. This is by Gregory interpreted as a gradual negation of every prejudice about the divine nature, resulting in an ecstasy the moment where Abraham recognizes that God is greater than any token by which He may be known $^{50}$. This "ecstasy" is, however, not the final goal of Abraham's journey. Rather it becomes the presupposition of faith, which Gregory, by paraphrasing Heb 11:1, interprets as related to hope rather than knowledge.

What should be noticed is how Gregory's idea of conception as a continuous process resembles his claim in the introduction to On the Life of Moses, where the perfection of human nature consists in its continuous growth in goodness. The reason for the endlessness of conception and human perfection is divine infinity.

It is this divine infinity, which makes it impossible to make a final, adequate description of what virtue looks like. Virtue can be described continuously through conception, it seems, but we can never make a final or adequate description of what it means to imitate the divine nature.

5. So, did this really change Gregory's moral epistemology? Though there are obvious changes in Gregory's thinking, it is far from obvious that Gregory did not have an apophatic theology and a corresponding moral epistemology from early on. In On Virginity (ca. 368) virginity is described by

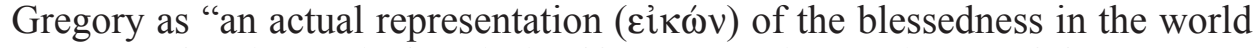
to come, showing as it does in itself so many signs ( $\varphi \dot{\varepsilon} \rho \omega \nu)$ of the presence of those expected blessings which are reserved for us there" ${ }^{51}$. But virginity,

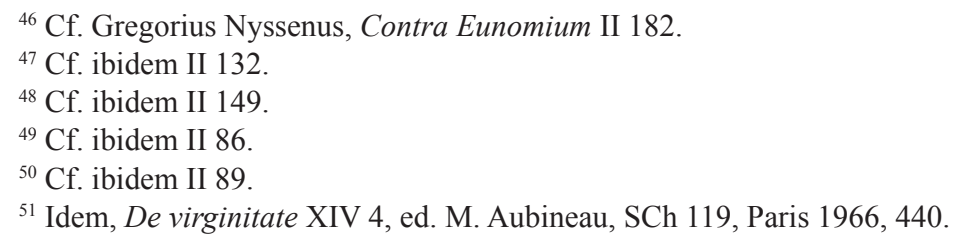


notes Gregory, is quite incapable of being described. The only sufficient way of praising virginity is "to show that virtue is above praise, and to evince our admiration of it by our lives rather than by our words" 52 . Hence Gregory from early on expresses what could be called a rather non-cognitive view on moral perfection, which might be considered partly apophatic.

But even if Gregory expresses a somewhat non-cognitive view on moral perfection in the early works, it is not obvious that he at this point believes moral perfection to be absolutely ineffable. Gregory describes himself as one who cannot attain or even describe the virgin's perfection. But this does not mean that moral perfection is absolutely ineffable and can only be defined in apophatic terms, but only that it is ineffable for the uninitiated ${ }^{53}$. The man whose thoughts are fixed upon the invisible is necessarily separated from all the ordinary events of life, says Gregory, but it is not obvious that the virtuous man can only understand himself in apophatic terms. Rather, in this early treatise, negations seems to be instruments for reaching a final higher stage, which is reached by separating oneself from evil ${ }^{54}$. This is abstraction, not unsaying.

It could also be argued that there are good examples of what could be called an aphairetic or abstractive moral epistemology in Gregory's later works, where moral perfection can be described in terms of learning to distinguish between oneself and one's surroundings ${ }^{55}$. But in the case of the later examples of an abstractive ethics, this does not preclude a truly apophatic ethics. Abstractive ethics only works as an early stage on the way to $\dot{\varepsilon} \pi \dot{\varepsilon} \kappa \tau \alpha \sigma \imath \varsigma$, as when Moses takes off his shoes in the first theophany.

Hope as a means of anticipating future perfection is central to the treatise On the Life of Moses. But it was also a theme in the early work On the Inscriptions of the Psalms. But in this treatise such anticipation seems to have a much more definite character. The one "who adheres to God through hope" ( $\delta i \dot{\alpha} \tau \hat{\omega} v$ $\left.\dot{\varepsilon} \lambda \pi^{\prime} \delta \omega v\right)$ becomes united with God, says Gregory in the first part On the Inscriptions of the Psalms ${ }^{56}$. Later in the treatise Gregory notes that the virtuous person "makes day for himself by hoping in the light, by means of which the

${ }^{52}$ Ibidem I, SCh 119, 260.

${ }^{53}$ If so, this would be reminiscent of Plato's claim that the good is hard to describe to all, a claim which is also quoted by Clement of Alexandria. Clement, however, reinterprets it as referring to absolute ineffability, something which Origen rightly criticizes, as Origen points out that Plato's meaning was properly only that only a few are capable of grasping the good, not that the good is in itself incapable of being grasped. In his early moral epistemology, I think that Gregory is closer to Origen than to Clement, in this respect.

${ }^{54}$ Cf. Gregorius Nyssenus, De virginitate XVIII 4, SCh 119, 474-476.

${ }^{55}$ For example in On the Song of Songs: "Our greatest safeguard is not to be ignorant of oneself and not to suppose that one is looking at oneself when in fact one is viewing something else, something that hangs about the outer edges of oneself" (idem, In Canticum canticorum, ed. H. Langerbeck, GNO 6, Leiden 1960, 63).

${ }^{56} \mathrm{Cf}$. idem, In inscriptiones Psalmorum, GNO 5, 43. 
darkness utterly disappears" 57 . Again we see the metaphors of light being more ultimate than those of darkness in On the Inscriptions of the Psalms.

My point is that the development in Gregory's thinking does not only mean a shift in emphasis. Heine's claim, that Gregory's discussion of the two first theophanies in On the Life of Moses reflects an anti-Eunomian emphasis, while the third expresses an anti-Origenist argument, is well-argued ${ }^{58}$. But my claim is that Gregory's interpretation of the third theophany to a large degree also expresses the epistemology and philosophy of language developed in the controversy against Eunomius and that this is what distinguishes Gregory's later ethics from his earlier ethics.

This is clear from what Gregory says early in his treatise On the Life of Moses about the infinity of the good and virtue as being indescribable because of the endless character of ethical progress. Gregory later notes that when God passes by Moses, this signifies that Moses cannot see God's face, since "good does not look good in the face, but follows it" 59 . He who follows sees the back, says Gregory and "to follow God wherever he might lead is to behold God". If "the face of God" can still be contemplated "in certain imprints" in the human soul, it can only be as negative imprints in the follower of Christ.

Much more could be said about this "ethics of following", as it could be called. Here it is enough to be aware that in the early treatise On the Inscrip-

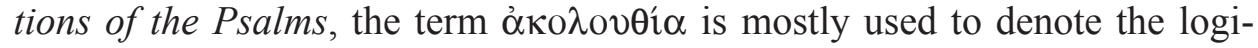
cal or ontological sequence of virtue ${ }^{60}$. Though a similar understanding of $\dot{\alpha} \kappa \circ \lambda \sigma v \theta i \alpha$ as a certain order or $\tau \dot{\alpha} \xi \xi \varsigma$ of the soul can be found in the later treatise On the Song of Songs ${ }^{61}$, we also find an understanding in On the Life of Moses which is much more likely to reflect the idea of conception, as developed in the Eunomian controversy. In On the Life of Moses, the idea of an endless progress in virtue is the ethical counterpart of conception, which in practice is expressed as following Christ by imitating his works.

It may also be asked what it means for Gregory to imitate the virtues of God if the virtues in the human soul no longer can be said to reflect the "divine form" in any positive way, as it could in On the Inscriptions of the Psalms. In his sermons on the Beatitudes Gregory argues that it is not possible for human beings to imitate the divine nature ${ }^{62}$. Instead human beings should be humble, as Christ became humble as he incarnated himself. Christians should imitate the works of Jesus Christ as known in the economy of salvation. Participation in the Godhead (or rather, the divine activities) must as such mean imitation

\footnotetext{
${ }^{57}$ Ibidem, GNO 5, 149.

${ }^{58}$ Cf. Heine, Perfection in the Virtuous Life, p. 194-195.

${ }^{59} \mathrm{Cf}$. Gregorius Nyssenus, De vita Moysis II 253, SCh 1bis, 280.

${ }^{60}$ Cf. e.g. idem, In inscriptiones Psalmorum, GNO 5, 117-118.

${ }^{61} \mathrm{Cf}$. idem, In Canticum canticorum, GNO 6, 148.

${ }^{62} \mathrm{Cf}$. idem, De beatitudinibus $1,4$.
} 
of the concrete historical works of God in the world ${ }^{63}$. Participation in God means participation in his philanthropy $\left(\varphi \imath \lambda \alpha \nu \theta \rho \omega \pi^{i} \alpha\right)$. A similar claim is made in On the Life of Moses, which Gregory concludes by talking of virtue in terms of "friendship" with God ${ }^{64}$.

To sum up, not only did the Eunomian controversy affect Gregory's trinitarian theology and his notions of language. It also had immense consequences for his view on moral epistemology. Where aphairetic theology was before used to gain an idea of what it means to imitate God, apophatic theology was later used as a means of pointing to the fact, that virtue can only be realized continously, not statically, in following Christ, something to which there can be no final end. To be sure, the point is that conception is the epistemological correspondent to epektasis, and that this is what connects apophatic theology with ethics through epistemology.

Gregory's apophatic claim is made both in the polemical context and in the moral philosophical context in order to point at the need for imitating that which can actually be known, namely the concrete works of Christ in history rather than the transcendent divine nature. Again, apophaticism is a way of affirming a Christocentric approach to human language as well as ethics. The heightened priority of Christology was the real effect of the Eunomian controversy, and the apophatic theology developed in order to ensure Christocentrism is what results in the new approach to epistemology and virtue in the later treatises of Gregory of Nyssa.

\section{(Summary)}

In early Christian thinking negative theology was often applied for polemical purposes, as a means of asserting the Christian distinction between God and everything else. Only later did negative theology develop into a philosophical and contemplative method. But even then it often kept a polemical function. This was the case for Gregory of Nyssa who applied forms of negative theology in his spiritual and exegetical works as well as in his polemical works, especially those against Eunomius. Using a distinction between aphairetic and apophatic kinds of negative theology, it can be argued that Gregory's theology, epistemology and philosophy of language, as developed during the Eunomian controversy, changed his negative theology in a fundamental way from an aphairetic theology, based on abstraction, to a thoroughly apophatic theology, based on negation in the sense of unsaying. It can further be argued that the results of this development influenced Gregory's ethical theories, his moral epistemology in particular. The main texts in question, besides Gregory's writings against Eunomius, are his early work on the inscriptions of the Psalms and his later work on the life of Moses. Both contain

${ }^{63}$ A well known theme. See D.L. Balás, Metousia Theou-Man's participation in God's Perfections according to Saint Gregory of Nyssa, Roma 1966, passim.

${ }^{64}$ Cf. Gregorius Nyssenus, De vita Moysis II 320, SCh 1bis, 326. 
reflections on Moses' spiritual development, but while the former uses mostly affirmative language, the latter involves a much higher degree of apophatic theology. This change is likely to have occurred during the Eunomian controversy where such things as God's infinity and the inability of human beings to grasp the divine essence became fundamental in such a way that apophatic, rather than aphairetic, language and thinking gained a central role in Gregory's theology as well as ethics.

\section{OD ABSTRAKCJI DO NIEWYPOWIEDZIANEGO. JAK KONTROWERSJA EUNOMIAŃSKA ZMIENIŁA ETYKĘ GRZEGORZA Z NYSSY Z AFAIRETYCZNEJ NA APOFATYCZNĄ}

\section{(Streszczenie)}

Teologia negatywna we wczesnochrześcijańskiej myśli była często stosowana w celach polemicznych jako sposób na rozróżnienie między Bogiem a wszystkim innym. Dopiero później rozwinęła się ona jako metoda filozoficzna i kontemplacyjna. Ale nawet wówczas często pełniła funkcję polemiczną. Tak było w przypadku Grzegorza z Nyssy, który stosował elementy teologii negatywnej w swych dziełach ascetycznych, egzegetycznych, a także polemicznych, zwłaszcza skierowanych przeciw Eunomiuszowi. Stosując rozróżnienie negatywnej teologii na afairetyczną i apofatyczna, autor dowodzi, że teologia, epistemologia i filozofia języka Grzegorza, wypracowane podczas sporów z Eunomiuszem, fundamentalnie zmieniły jego negatywną teologię $z$ afairetycznej, bazującej na abstrakcji, na apofatyczna, opartą na negacji - w sensie niemożliwego do wypowiedzenia. Wykazuje też, że rezultaty tego rozwoju wpłynęły na etyczne teorie Grzegorza, zwłaszcza na jego epistemologię moralną.

Głównymi tekstami, dotyczącymi tej problematyki, oprócz dzieł Grzegorza przeciw Eunomiuszowi, są: wczesne pismo $O$ tytułach Psalmów i jego późniejszy traktat $O$ życiu Mojżesza. Oba zawierają refleksje na temat duchowego rozwoju Mojżesza, z tym że w pierwszym Grzegorz używa głównie języka afirmatywnego, w drugim zaś stosuje zaawansowaną teologię apofatyczną. Ta zmiana nastapiła prawdopodobnie podczas kontrowersji eunomiańskiej, w której takie elementy jak nieskończoność Boga i niemożność dotarcia przez człowieka do Boskiej istoty stały się fundamentalne do tego stopnia, że apofatyczny, a nie afairetyczny język i myślenie odegrały kluczową rolę w teologii, jak również w etyce Grzegorza.

Key words: Gregory of Nyssa, Eunomius, ethics.

Słowa kluczowe: Grzegorz z Nyssy, Eunomiusz, etyka. 


\section{BIBLIOGRAPHY}

\section{Sources}

Eunomius, Apologia, ed. R.P. Vaggione, in: Eunomius, The Extant Works, Oxford 1987, 43-75.

Gregorius Nazianzenus, Oratio 28 (De theologia), ed. P. Gallay - M. Jourjon, SCh 250, Paris 1978, 100-174.

Gregorius Nyssenus, Contra Eunomium, ed. W. Jaeger, GNO 1-2, Leiden 1960.

Gregorius Nyssenus, De beatitudinibus, ed. J.F. Callahan, GNO 7/2, Leiden 1992.

Gregorius Nyssenus, De virginitate, ed. M. Aubineau, SCh 119, Paris 1966.

Gregorius Nyssenus, De vita Moysis, ed. J. Daniélou, SCh 1bis, Paris 1987.

Gregorius Nyssenus, In Canticum canticorum, ed. H. Langerbeck, GNO 6, Leiden 1960.

Gregorius Nyssenus, In inscriptiones Psalmorum, ed. J. Donough, GNO 5, Leiden 1962.

\section{Literature}

Balás D.L., Metousia Theou - Man's participation in God's Perfections according to Saint Gregory of Nyssa, Roma 1966.

Brightman R.S., Apophatic Theology and Divine Infinity in St. Gregory of Nyssa, GOTR 18 (1973) 97-114.

DaniéLou J., Gospel message and Hellenistic culture, Westminster 1973.

DaniéLou J., Le symbole de la caverne chez Grégoire de Nysse, in: Mullus. Festschrift Theodor Klauser, Münster 1964, 43-51.

HäGG H.F., Clement of Alexandria and the Beginnings of Christian Apophaticism, Oxford 2006.

HeIne R., Perfection in the Virtuous Life: A study of the relationship between edification and polemical theology in Gregory of Nyssa's "De Vita Moysis", Cambridge (MA) 1975 .

LANGerbeck H., Zur Interpretation Gregors von Nyssa, ThL 82 (1957) 81-90.

Meredith A., Plato's Cave ("Republic" VII 514a-517e) in Origen, Plotinus, and Gregory of Nyssa, StPatr 27 (1991) 49-61.

Mortley R., From Word to Silence, II: The Way of Negation, Christian and Greek, Bonn 1986.

Mortley R., What is Negative Theology? The Western Origins, "Prudentia" supplementary number: Via Negativa Conference - University of Sydney, (1981) 5-12.

Palmer D.W., Atheism, Apologetic, and Negative Theology in the Greek Apologists of the Second Century, VigCh 37/3 (1983) 234-259.

Rondeau M.J., Exégèse du Psautier et anabase spirituelle chez Grégoire de Nysse, in: Epektasis: Mélanges patristiques offerts au cardinal Jean Daniélou, Paris 1972, 517-531.

Sokolowski R., The God of Faith and Reason: Foundations of Christian Theology, Washington D.C. 1995.

Steenbuch J., Doing the Unthinkable: Theology and Moral Epistemology in Three Early Christian Thinkers, Copenhagen 2014.

The Brill Dictionary of Gregory of Nyssa, ed. L.F. Mateo-Seco - G. Maspero, Brill 2009. Wissink J., Two Forms of Negative Theology Explained Using Thomas Aquinas, in: Flight of the Gods: Philosophical Perspectives on Negative Theology, ed. I.N. Bulhof - L. ten Kate, Fordham 2000, 100-120. 